\title{
Erratum to: Transoral endoscopic neck surgery: feasibility and safety in a porcine model based on the example of thymectomy
}

Thomas Wilhelm • Tahar Benhidjeb

Published online: 2 May 2011

(C) Springer Science+Business Media, LLC 2011

Erratum to: Surg Endosc

DOI 10.1007/s00464-010-1305-6

The full list of authors was not included. The authors and their affiliations are listed above and below.

The online version of the original article can be found under doi:10.1007/s00464-010-1305-6.

T. Wilhelm ( $\square)$

Department of Otolaryngology, Head/Neck \& Facial Plastic

Surgery, HELIOS Klinikum Borna, Borna, Germany

e-mail: thomas.wilhelm@helios-kliniken.de

T. Benhidjeb

Department of General, Visceral and Thoracic Surgery,

University Medical Center Hamburg-Eppendorf, Hamburg,

Germany

T. Benhidjeb

The New European Surgical Academy (NESA), Berlin,

Germany 